\title{
Alkali Pretreatment and Enzymatic Hydrolysis of Australian Timber Mill Sawdust for Biofuel Production
}

\author{
Raymond Martin Trevorah and Maazuza Z. Othman \\ School of Civil, Environmental and Chemical Engineering, Royal Melbourne Institute of Technology, P.O. Box 2476,
} Melbourne, VIC 3001, Australia

Correspondence should be addressed to Raymond Martin Trevorah; raymondtrevorah@gmail.com

Received 30 June 2015; Revised 21 September 2015; Accepted 27 September 2015

Academic Editor: Siqing Liu

Copyright (c) 2015 R. M. Trevorah and M. Z. Othman. This is an open access article distributed under the Creative Commons Attribution License, which permits unrestricted use, distribution, and reproduction in any medium, provided the original work is properly cited.

\begin{abstract}
This study investigated the potential use of alkali pretreatment of sawdust from Australian timber mills to produce bioethanol. Sawdust was treated using 3-10\% w/w NaOH at temperatures of 60,121 , and $-20^{\circ} \mathrm{C}$. Two pathways of production were trialled to see the impact on the bioethanol potential, enzymatic hydrolysis for glucose production, and simultaneous saccharification and fermentation (SSF) for ethanol production. The maximum yields obtained were at $121^{\circ} \mathrm{C}$ and $-20^{\circ} \mathrm{C}$ using $7 \% \mathrm{NaOH}$, with $29.3 \%$ and $30.6 \%$ ethanol yields after 0.5 and $24 \mathrm{hr}$, respectively, these treatments yielded $233 \%$ and $137 \%$ increase from the $60^{\circ} \mathrm{C}$ counter parts. A notable trend of increased ethanol yields with increased $\mathrm{NaOH}$ concentration was observed for samples treated at $60^{\circ} \mathrm{C}$; for example, samples treated using $10 \% \mathrm{NaOH}$ produced 1.92-2.07 times more than those treated using $3 \% \mathrm{NaOH}$. FTIR analysis showed reduction in crystallinity correlating with increased ethanol yields with the largest reduction in crystallinity in the sample treated at $-20^{\circ} \mathrm{C}$ for $24 \mathrm{hr}$ with $7 \% \mathrm{NaOH}$.
\end{abstract}

\section{Introduction}

Waste lignocellulose is the most abundant potential source for biofuels on the planet [1] but it is largely underutilised. A significant proportion of lignocellulosic waste is incinerated, composted, sent to landfill, or left on site to degrade, and this adds to the power demands, greenhouse gas emissions, and operational costs of agriculture and forestry practices [2]. Increasing fuel prices and action to combat climate change have created greater opportunity for ethanol as a renewable fuel to help meet transport fuel demand. Unlike traditional first generation starch or sugar based techniques [3], second generation ethanol provides a favourable alternative, producing lower greenhouse gas emissions and utilising waste products. In Australia, a significant volume of wood wastes is generated by different industries and activities, equating to 1654000 tons per annum which is sent to landfill [4]. Approximately $6.5 \mathrm{Mt}$ of waste wood was produced in Australia by forestry and timber milling sites in 2011 [5]. Wood waste as a biofuel feedstock has gained momentum over the past decade with significant developments in techniques and applications [5-8].

Hardwoods are a lignocellulosic biomass, with a significant proportion of cellulose between 45 and 55\% w/w. Hemicellulose also composes a large proportion of the mass accounting for $24-40 \% \mathrm{w} / \mathrm{w}$ [3]. Lignin in hardwoods comprises $18-25 \% \mathrm{w} / \mathrm{w}$ unlike the $25-35 \% \mathrm{w} / \mathrm{w}$ of softwoods. There are also variations in lignin type with the hardwoods containing high proportions of guaiacyl and syringyl monomer units, unlike softwoods which are predominantly guaiacyl [9]. This greater presence of syringyl may permit less severe pretreatments as it has been found to be more susceptible to alkali pretreatments $[10,11]$.

The lignin-hemicellulose matrix surrounding the cellulose microfibril provides the first hurdle in enzymatic hydrolysis, as it prevents the enzymes' access to the cellulose, inhibiting the hydrolysis of the cellulose. This can be overcome by the removal or modifications of lignin and or hemicellulose, increasing the pore space allowing enzyme access to the cellulose microfibrils [12]. 
It has been shown that alkali pretreatment increases access to the cellulose by saponification of the intermolecular ester bonds between hemicellulose and lignin. The cleaving of these links can cause solubilisation of lignin and hemicellulose [13]. Alkali pretreatment can also result in the removal of acetyl and various uronic acid substitutions on hemicelluloses $[14,15]$. Xylans have been shown to be more susceptible to lower concentrations of alkali than glucomannan, suggesting that hardwoods would be more susceptible to lower levels of alkali pretreatment [16], which is consistent with the results reported by Mirahmadi et al. [17], who observed larger yields from hardwoods pretreated at low temperature with $\mathrm{NaOH}$.

Alkali pretreatment has been observed to decrease cellulose crystallinity and the degree of polymerisation, which is considered to occur due to swelling of the internal cellulose microfibrils increasing the amount of amorphous regions of cellulose microfibrils $[18,19]$, thus increasing access for enzymes [20]. Alkali pretreatment can induce the conversion of cellulose I $\beta$ into cellulose II hydrate, which possesses a larger structure and faster enzymatic hydrolysis rate [21]. It is also known to increase amorphous cellulose regions and decrease degree of polymerisation increasing the susceptibility to enzymatic degradation of the lignocellulose [13].

The use of moderate temperatures in alkali pretreatment can prevent the creation of furfural, hydroxymethylfurfural, and organic acids, reducing the loss of usable sugars [22]. Preventing the formation of these products aids in successful operation of SSF systems as they are inhibitory to Saccharomyces cerevisiae [23].

The effect of pretreatment conditions, for example, temperature, time, and alkali dosage, has been studied by many researchers $[17,24]$. It has been reported that temperatures in excess of $100^{\circ} \mathrm{C}$ can lead to destruction of the lignin and hemicelluloses, which significantly increases susceptibility to enzyme hydrolysis. For example, Mirahmadi et al. achieved a $54.76 \%$ ethanol yield from birch at $100^{\circ} \mathrm{C}$ [17]. Similarly lower temperatures and the addition of urea also increased ethanol production and cellulose dissolution, with Zhao et al. achieving over $60 \%$ glucose yields for spruce pretreated at $-15^{\circ} \mathrm{C}[24]$.

A large number of research studies have looked into the feasibility of pretreatment of lignocellulosic materials with $\mathrm{Ca}(\mathrm{OH})_{2}$ and $\mathrm{NaOH}[13]$. It has been found that $\mathrm{Ca}(\mathrm{OH})_{2}$ is significantly cheaper and easier to recover than $\mathrm{NaOH}$ [25]. However it is not as strong as alkali and requires longer exposure times [26]; $\mathrm{NaOH}$ was selected for this investigation.

Simultaneous saccharification and fermentation (SSF) systems for the production of ethanol from lignocellulosic material have been thoroughly investigated. SSF has the ability to prevent end-product inhibition by conversion of glucose to ethanol, resulting in improved yields [27] compared to many traditional separate saccharification/hydrolysis and fermentation systems. Therefore SSF was selected for this investigation due to these benefits, although it can suffer minor limitations concerning optimisation of temperature [28].

This investigation will be into the possibility of pretreatment at $60^{\circ} \mathrm{C}$ over $0.5-2 \mathrm{hr}$ with 3,7 , and $10 \% \mathrm{NaOH}$. Three comparative treatments were also assessed with $7 \% \mathrm{NaOH}$ at $121^{\circ} \mathrm{C}$ for $0.5 \mathrm{hr}$ and $-20^{\circ} \mathrm{C}$ for 2 and $24 \mathrm{hr}$.

\section{Materials and Methods}

2.1. Sawdust. The sawdust mixture utilised in this investigation was collected from a timber mill located in regional Victoria. The sawdust mixture used contained a mixture of eucalyptus hardwoods and nonnative softwoods; the waste wood samples were ground utilising a bladed mill (IKA analytical mill) and separated with a ASTM number 18 mesh $1 \mathrm{~mm}$ sized sieve.

2.2. Enzymes. The cellulase enzyme complex Accellerase 1500 (enzyme solutions, Australia) was used in the hydrolysis and SSF systems. The cellulase activity in filter paper units (FPU) was $45.6 / \mathrm{mL}$ measured as described in $[29,30]$. In addition $\beta$-glucanase activity of $(620.0 \pm 125 \mathrm{pNP}$ G U/g) was as stated by supplier. Cellulase activity was measured before each test to ensure consistent loadings. $\beta$-glucanase enzymes activity is reported in terms of nitrophenol liberation from para-nitrophenyl-B-D glucopyranoside pNP G U/g.

2.3. Inoculum. A freeze dried thermo-tolerant Saccharomyces cerevisiae (Thermosac Dry; Lallemand Biofuels \& Distilled Spirits) was utilised as the inoculum culture in the SSF reactors. Prior to inoculating the SSF reactor system, dry yeasts were hydrated with deionised water for 30 minutes at $38^{\circ} \mathrm{C}$ in a water bath (Lallemand Biofuels \& Distilled Spirits). Following hydration, the inoculum was rinsed and washed 3 times via centrifuge for 5 minutes at $4400 \mathrm{rpm}$ with deionised (DI) water to remove trace glucose and nutrients. The dry cell mass was prepared by drying samples at $80^{\circ} \mathrm{C}$ for $24 \mathrm{hr}$ [31].

2.3.1. Alkali Pretreatment. The first phase of alkali pretreatment of sawdust samples was carried out using 3\%, 7\%, and $10 \% \mathrm{NaOH}$ solutions $(\mathrm{w} / \mathrm{w})$ at a temperature of $60^{\circ} \mathrm{C}$ and exposure times of $0.5,1$, and $2 \mathrm{hr}(\mathrm{s})$ with a solid to liquid ratio of $1: 10 \mathrm{w} / \mathrm{v}$, based on the works previously undertaken by $[17,24]$. The second phase of alkali pretreatment was carried out at $-20^{\circ} \mathrm{C}$ and $121^{\circ} \mathrm{C}$ with a $7 \% \mathrm{NaOH}$ solution for $0.5,2$, and $24 \mathrm{hr}$. Following pretreatment sawdust mixture samples were rinsed until a neutral $\mathrm{pH}$ 7-8 was reached and was then vacuum filtered and stored at $4^{\circ} \mathrm{C}$ for future use.

2.3.2. Cellulose Hydrolysis. Hydrolysis of cellulose in the pretreated sawdust was undertaken using $118 \mathrm{~mL}$ reactors with a working mass of $20 \mathrm{~g}$. Substrate loadings of $3 \mathrm{~g}_{\mathrm{TS}}$ of pretreated sawdust mixture, a cellulase dosage of $9.1 \mathrm{FPU} / \mathrm{g}_{\mathrm{TS}}$ and $325 \pm$ $63 \mathrm{pNPGU/g}$ cellulose, were applied to each reactor. A citrate buffer solution of $0.05 \mathrm{M}$ was added to the reactors to achieve and maintain a pH of $4.95 \pm 0.15$ [31]. Midlength cellulose (Sigma Aldrich) was used as a control. Antibacterial tetracycline and fungicide cycloheximide were applied at $4 \mu \mathrm{g} / \mathrm{mL}$ and $3 \mu \mathrm{g} / \mathrm{mL}$, respectively, to all hydrolysis reactors [32] to prevent contamination. Following the addition of the enzyme, the reactors were sealed and placed in a rotating incubator at $50^{\circ} \mathrm{C}$ and $130 \mathrm{rpm}$. Samples were collected via an open tip pipette after $3,8,24,48,70$, and $96 \mathrm{hr}$. The samples were submerged in a water bath at $100^{\circ} \mathrm{C}$ for 5 minutes, followed by an ice bath and centrifuging at $4400 \mathrm{rpm}$ for 
TABLE 1: Composition of sawdust before and after pretreatment with $\mathrm{NaOH}$.

\begin{tabular}{|c|c|c|c|c|c|c|c|c|}
\hline Dose & Temp. $\left({ }^{\circ} \mathrm{C}\right)$ & $\begin{array}{l}\text { Time } \\
\text { (hr) }\end{array}$ & $\begin{array}{c}\text { Cellulose (\%) } \\
\text { w/w }\end{array}$ & $\begin{array}{c}\text { Xylan (\%) } \\
\text { w/w }\end{array}$ & $\begin{array}{c}\text { Galactans } \\
(\%) \mathrm{w} / \mathrm{w}\end{array}$ & $\begin{array}{c}\text { ASL }^{*}(\%) \\
\text { w/w }\end{array}$ & $\begin{array}{c}\mathrm{AIL}^{* *}(\%) \\
\mathrm{w} / \mathrm{w} \\
\end{array}$ & $\begin{array}{c}\text { Extractives } \\
(\%) \mathrm{w} / \mathrm{w}\end{array}$ \\
\hline & Untreated sawdust & & $41.0 \pm 2.8$ & $6.0 \pm 3.0$ & $1.1 \pm 1.5$ & $5.7 \pm 0.3$ & $25.5 \pm 4.2$ & $8.05 \%$ \\
\hline & 60 & 0.5 & $39.9 \pm 1.4$ & $4.76 \pm 0.4$ & $0.5 \pm 0.2$ & $4.9 \pm 0.6$ & $26.5 \pm 1$ & $0.96 \%$ \\
\hline \multirow[t]{3}{*}{$3 \%$} & & 1 & $44.6 \pm 1$ & $4.76 \pm 0.7$ & $0.3 \pm 0.4$ & $4.7 \pm 0.4$ & $31.7 \pm 0.3$ & $1.16 \%$ \\
\hline & & 2 & $48.3 \pm 7.3$ & $4.18 \pm 0.3$ & $1.3 \pm 0.8$ & $4.7 \pm 0.7$ & $31.8 \pm 0.8$ & $0.75 \%$ \\
\hline & & 0.5 & $45.2 \pm 3.9$ & $4.08 \pm 0.1$ & $0.9 \pm 0.9$ & $4.1 \pm 0.3$ & $28.2 \pm 4.9$ & $0.52 \%$ \\
\hline \multirow[t]{3}{*}{$7 \%$} & & 1 & $47.8 \pm 7.4$ & $3.81 \pm 0.1$ & $0.3 \pm 0.1$ & $4.0 \pm 0.1$ & $29.6 \pm 0.8$ & $0.69 \%$ \\
\hline & & 2 & $50.9 \pm 6.0$ & $4.5 \pm 1.0$ & $0.3 \pm 0.0$ & $3.8 \pm 0.4$ & $28.8 \pm 4.3$ & $0.87 \%$ \\
\hline & & 0.5 & $51.7 \pm 3.6$ & $6.4 \pm 2.1$ & $1.4 \pm 1.2$ & $4.3 \pm 0.4$ & $26.9 \pm 3.2$ & $0.72 \%$ \\
\hline \multirow[t]{3}{*}{$10 \%$} & & 1 & $48.3 \pm 0.8$ & $5.9 \pm 0.9$ & $0.5 \pm 0.1$ & $3.8 \pm 0.1$ & $27.7 \pm 5.3$ & $0.87 \%$ \\
\hline & & 2 & $48.1 \pm 4.0$ & $4.9 \pm 0.4$ & $0.3 \pm 0.1$ & $4.5 \pm 0.2$ & $31.7 \pm 0.6$ & $0.85 \%$ \\
\hline & -20 & 24 & $51.0 \pm 2.0$ & $4.3 \pm 0.7$ & $0.4 \pm 0.0$ & $4.4 \pm 0.2$ & $24.0 \pm 2.7$ & $0.59 \%$ \\
\hline \multirow[t]{2}{*}{$7 \%$} & -20 & 2 & $49.5 \pm 4.9$ & $4.7 \pm 1.2$ & $0.4 \pm 0.3$ & $4.4 \pm 0.1$ & $26.8 \pm 1.2$ & $0.72 \%$ \\
\hline & 121 & 0.5 & $51.8 \pm 3.5$ & $4.4 \pm 1.0$ & $0.0 \pm 0.1$ & $3.8 \pm 0.2$ & $23.1 \pm 2.6$ & $0.51 \%$ \\
\hline
\end{tabular}

${ }^{*}$ ALS represents acid soluble lignin. ${ }^{* *}$ AIL represents acid insoluble lignin.

5 minutes. The supernatant was filtered with $0.45 \mu \mathrm{m}$ nylon filters and analysed for saccharides using HPLC. The glucose produced from hydrolysis is reported in percentage of glucose that can be produced from the cellulose in the sample.

\subsubsection{Simultaneous Saccharification and Fermentation (SSF).} SSF was carried out in $250 \mathrm{~mL}$ reactors with a working mass of $50 \mathrm{~g}$, and a substrate loading of $7.5 \mathrm{~g}$ Ts was used to maintain consistency with the hydrolysis systems. Within the operating reactors $0.05 \mathrm{M}$ citrate buffering solution, $2 \%$ peptone and $1 \%$ yeast extract were used to maintain the $\mathrm{pH}$ and provide nutrients for microbial growth [31]. All rectors received sawdust an approximate loading of $6 \%$ cellulose calculated form TS equivalent assuming cellulose concentration of $40 \%$. The reactors received enzyme at a loading of $22.8 \mathrm{FPU} / \mathrm{g}_{\text {cellulose }}$ and $50.0 \mathrm{FPU} / \mathrm{g}_{\text {cellulose }}$ equating to approximately 9.1 and $20.0 \mathrm{FPU} / \mathrm{g}_{\mathrm{TS}}$ sawdust mixture. The inoculum was dosed to reactors to produce an $\mathrm{OD}_{600}$ of 0.5 . The reactors were flushed with $\mathrm{N}_{2}$ and a two-part plastic air trap system was used to maintain anaerobic conditions and fermentation was undertaken in a rotary incubator at $38^{\circ} \mathrm{C}$ and $130 \mathrm{rpm}$. After sample collection the flask was degassed. Medium length cellulose fibres (Sigma Aldrich) were used as the feedstock for control reactors for 22.8 and $50.0 \mathrm{FPU} / \mathrm{g}_{\text {cellulose }}$. All SSF reactors were run in duplicate. Following acquisition samples were centrifuged and filtered before analysis.

2.3.4. Analytical Techniques. Measurements of TS and volatile solids (VS) were carried out according to the standard methods as described in $[33,34]$. Acid soluble lignin (ASL), acid insoluble lignin (AIL), cellulose, and hemicellulose analysis were carried out according to the method descried in [35], except that extraction was carried out using a microwave reaction system (Multiwave Pro, Anton Paar) in place of the use of Soxhlet solvent extraction apparatus. Saccharide concentration was determined using HPLC (Shimadzu UFLC) with a Hi-PLEX $\mathrm{Pb}$ and Serex $\mathrm{Pb}^{2+}$ and $\mathrm{Na}^{+}$columns (Phenomonex); a flow of $0.3 \mathrm{~mL} / \mathrm{min}$ at $85^{\circ} \mathrm{C}$ and a refraction index detector were used. Ethanol concentration was measured using gas chromatography (Varian GC420) fitted with a flame ionization detector (FID) and BP-21 column (Agilent). The system was operated with $\mathrm{N}_{2}$ as a carrier gas with the injector at $250^{\circ} \mathrm{C}$ oven at $50^{\circ} \mathrm{C}$ and FID of $275^{\circ} \mathrm{C}$ and a carrier gas flow of $1.1 \mathrm{~mL} / \mathrm{min}$. The ethanol produced was reported in ethanol production as percentage of theoretical cellulosic ethanol yield using a conversion factor of $0.5667 \mathrm{~g}_{\text {(ethanol) }} / \mathrm{g}_{\text {(cellulose) }}$ [31].

2.3.5. FTIR Spectroscopy. FTIR analysis was undertaken utilising a Perkin Elmer Spectrum 100 FTIR within a spectrum of $600-4000 \mathrm{~cm}^{-1}$. Before analysis samples were dried in a $35^{\circ} \mathrm{C}$ oven [36]. Samples were ground and sieved through a $106 \mu \mathrm{m}$ sieve (number 140), compressed, and analysed for 32 scans. Absorption bands at 1435, 1330, and $898 \mathrm{~cm}^{-1}$ were analysed as these are representative of the crystalline structure of cellulose, bands located at 1435 and $1330 \mathrm{~cm}^{-1}$ being more prevalent in cellulose $\mathrm{I} \beta$ and those at $898 \mathrm{~cm}^{-1}$ being more prevalent in cellulose II [37]. A novel measure of change in crystalline state was calculated by $A_{1330} / A_{898}$ and $A_{1435}$, $A_{1423} / A_{898}$. Both of these methods potentially face issues with interference due to close peaks occurring from syringyl rings at $1315 \mathrm{~cm}^{-1}$ [38] and aromatic ring stretching at $1422 \mathrm{~cm}^{-1}$ [39]. Total crystallinity was also analysed using two measurements of $\mathrm{CH}$ stretching with a ratio of $A_{1375} / A_{2900}$ [40]. The analysis investigated the absorbance peaks at 1218, 1268 (C-O guaiacyl rings), and $1315 \mathrm{~cm}^{-1}$ (C-O of syringyl rings) [41, 42] as well as the presence of any troughs at 1140-1111 as this could signify a drop in S unit lignin [39, 42, 43]. These areas were analysed for the potential impacts on lignin functional groups within the samples.

\section{Results and Discussion}

3.1. Compositional Analysis of Sawdust. The composition of the sawdust before and after alkali pretreatment is given in Table 1. The cellulose content following pretreatment increased from $41.0 \%$ to $44.6-51.8 \%$ following pretreatments 
TABLE 2: Impact of pretreatment on structural composition ratios.

\begin{tabular}{|c|c|c|c|c|c|}
\hline Dose & Temp. $\left({ }^{\circ} \mathrm{C}\right)$ & Time (hr) & Cellulose/hemicellulose & Lignin/cellulose & Lignin/hemicellulose \\
\hline \multicolumn{3}{|c|}{ Untreated sawdust } & 5.81 & 0.76 & 4.42 \\
\hline \multirow{3}{*}{$3 \%$} & 60 & 0.5 & 7.52 & 0.79 & 5.92 \\
\hline & & 1 & 7.40 & 0.82 & 6.04 \\
\hline & & 2 & 5.49 & 0.76 & 4.15 \\
\hline \multirow{3}{*}{$7 \%$} & & 0.5 & 6.21 & 0.72 & 4.44 \\
\hline & & 1 & 9.77 & 0.71 & 6.87 \\
\hline & & 2 & 10.70 & 0.64 & 6.85 \\
\hline \multirow{3}{*}{$10 \%$} & & 0.5 & 6.61 & 0.61 & 3.99 \\
\hline & & 1 & 7.51 & 0.65 & 4.90 \\
\hline & & 2 & 9.17 & 0.76 & 6.89 \\
\hline \multirow{3}{*}{$7 \%$} & -20 & 24 & 10.97 & 0.56 & 6.10 \\
\hline & -20 & 2 & 9.71 & 0.63 & 6.13 \\
\hline & 121 & 0.5 & 11.57 & 0.52 & 6.01 \\
\hline
\end{tabular}

except sawdust treated with $3 \% \mathrm{NaOH}$ for $0.5 \mathrm{hr}$ at $60^{\circ} \mathrm{C}$ which appeared to show a decreased cellulose concentration. Xylan content after pretreatment decreased from the $6.0 \%$ in the untreated sawdust in all treatments with exception of $10 \%$ $\mathrm{NaOH}$ exposed to $0.5 \mathrm{hr}$. Further it was observed that the cellulose/hemicellulose ratio of all pretreatments increased with the exception of those treated with $3 \% \mathrm{NaOH}$ for $2 \mathrm{hr}$ at $60^{\circ} \mathrm{C}$ (Table 2).

Significant extractive removal was observed for all alkali pretreated sawdust, reduced from $8.05 \%$ down to approximately $\sim 1 \%$ or less in treated samples (Table 1 ). The removal of extractives was proportional to the pretreatment times and concentrations of $\mathrm{NaOH}$ for pretreatments at $60^{\circ} \mathrm{C}$, but all samples reached $>86 \%$ extractive removal.

Lignin removal occurred in all pretreated samples with ASL content reduced from the $6.2 \%$ of the untreated samples to $\leq 5 \% \mathrm{w} / \mathrm{w}$. AIL content of pretreatments of $60^{\circ} \mathrm{C}$ with $3 \%$ $\mathrm{NaOH}$ did not show significant reduction of total lignin due to the lack of reduction in the lignin/cellulose ratio as shown in Table 2. Pretreatment using $\mathrm{NaOH}$ of $7 \%$ for $2 \mathrm{hr}$ and $10 \%$ for 0.5 and $1 \mathrm{hr}$ demonstrated reduction in total lignin. The largest reduction in the lignin/cellulose ratio was by samples pretreated at $121^{\circ} \mathrm{C}$ for $0.5 \mathrm{hr}$ with a ratio of 0.52 (Table 2).

The FTIR analysis displayed in Figure 1 shows that the broad peak between 1760 and $1680 \mathrm{~cm}^{-1}$ found in the untreated wood was removed by all levels of pretreatment. This peak represents acetyl or acid groups, as well as ketones, carbonyls, and esters attributed to xylans $\mathrm{C}=\mathrm{O}[38,43]$.

The reductions in peaks at $1250 \mathrm{~cm}^{-1}$ may relate to the removal of xyloglucan acetyl groups or reduction in $\mathrm{COOH}$ groups in the lignin hemicellulose matrix $[39,42]$. This correlates with overall reductions in xylose concentration after pretreatment shown in Table 1 and the increase in cellulose/hemicellulose ratio.

Pretreatment of the sawdust at $60^{\circ} \mathrm{C}$ showed two apparent trends in relation to the composition of the sawdust. Firstly as pretreatment time increased levels of xylose decreased, secondly concentrations of 7 and $10 \% \mathrm{NaOH}$ produced a greater reduction in xylose and lignin removal with exception

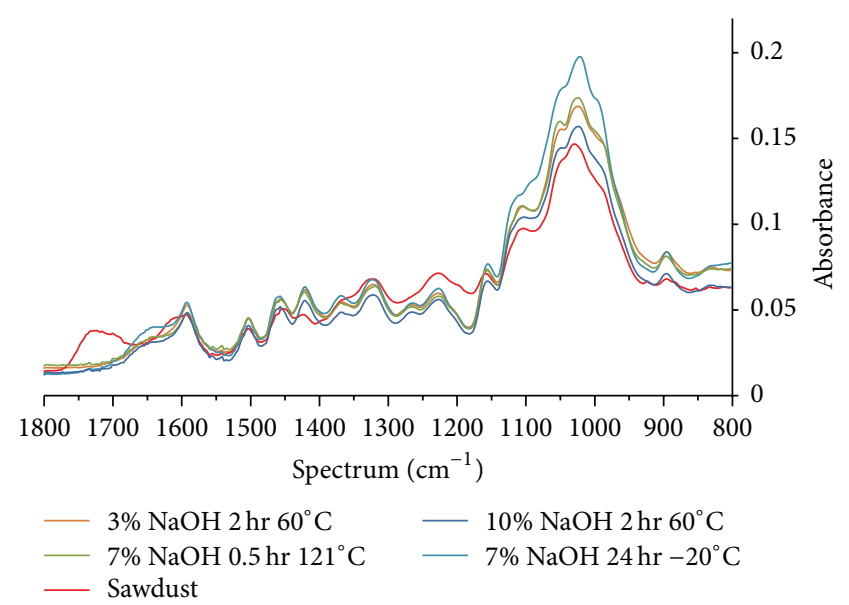

FIGURE 1: FTIR analysis of a verity of $\mathrm{NaOH}$ pretreated sawdust between 800 and $1800 \mathrm{~cm}^{-1}$.

of $10 \% \mathrm{NaOH}$ for $2 \mathrm{hr}$ and $3 \% \mathrm{NaOH}$ for $0.5 \mathrm{hr}$. Notably samples treated with $7 \% \mathrm{NaOH}$ produced a larger cellulose/xylan ratio suggesting that more xylans had been removed in these treatments than that of the $10 \%$ solutions; conversely the $10 \%$ solution displayed a reduction in the lignin/cellulose ratio suggesting greater lignin removal than the $7 \%$ counter parts.

3.1.1. Hydrolysis of $\mathrm{NaOH}$ Pretreated Sawdust. The hydrolysis of the sawdust pretreated at $60^{\circ} \mathrm{C}$ yielded between 5.8 and $16.2 \%$ of potential glucose production compared to untreated sawdust which could only produce $0.5 \pm 0.2 \%$ as shown in Table 3. The highest glucose yield obtained was $16.2 \pm 1.4 \%$, produced from sawdust pretreated using $10 \% \mathrm{NaOH}$ for $0.5 \mathrm{hr}$ at $60^{\circ} \mathrm{C}$ after $70 \mathrm{hr}$ of saccharification. Hydrolysis produced yields lower than those observed within SSF systems with exceptions of $7 \% \mathrm{NaOH}$ for 0.5 and $2 \mathrm{hr}$ and $10 \% \mathrm{NaOH}$ for $0.5 \mathrm{hr}$ at $60^{\circ} \mathrm{C}$. However, when accounting for the natural fermentation limitations of the $S$. cerevisiae fermentation system only two samples achieved greater yields with 0.15 and $0.66 \%$ increased ethanol than the SSF counterparts; these 
TABLE 3: Peak glucose production in cellulose hydrolysis systems of sawdust pretreated with $\mathrm{NaOH}$ at $60^{\circ} \mathrm{C}$.

\begin{tabular}{lccccc}
\hline $3 \% \mathrm{NaOH} 60^{\circ} \mathrm{C}$ & Glucose yield (\%) & $7 \% \mathrm{NaOH} 60^{\circ} \mathrm{C}$ & Glucose yield (\%) & $10 \% \mathrm{NaOH} 60^{\circ} \mathrm{C}$ & $\mathrm{Glucose}$ yield $(\%)$ \\
\hline $0.5 \mathrm{hr}$ & $8.1 \pm 3.6 \%$ & $0.5 \mathrm{hr}$ & $11.6 \pm 3.2 \%$ & $0.5 \mathrm{hr}$ & $16.2 \pm 1.4 \%$ \\
$1 \mathrm{hr}$ & $5.8 \pm 0.6 \%$ & $1 \mathrm{hr}$ & $9.4 \pm 3.6 \%$ & $1 \mathrm{hr}$ & $9.9 \pm 7.0 \%$ \\
$2 \mathrm{hr}$ & $7.0 \pm 1.5 \%$ & $2 \mathrm{hr}$ & $11.2 \pm 3.4 \%$ & $2 \mathrm{hr}$ & $12.9 \pm 1.4 \%$ \\
\hline
\end{tabular}

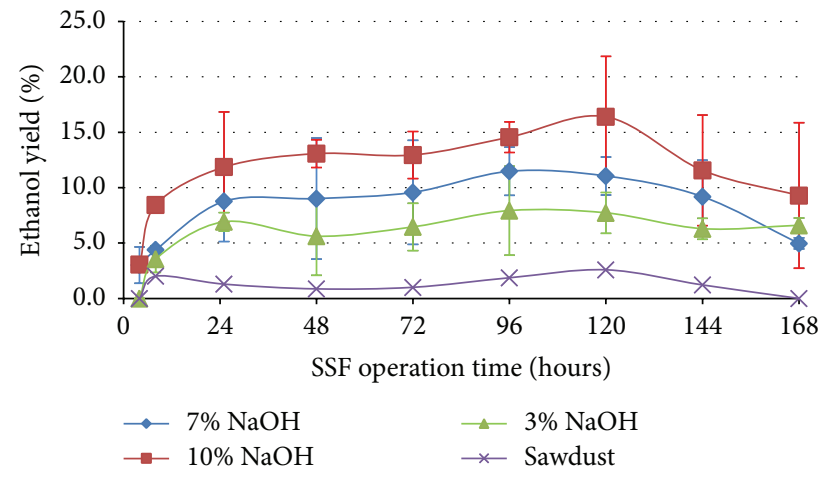

FIGURE 2: Ethanol yield from sawdust pretreated for $2 \mathrm{hr}$ at $60^{\circ} \mathrm{C}$ in $\mathrm{NaOH}$ solution, with $20 \mathrm{FPU} / \mathrm{g}_{\mathrm{TS}}$.

were the samples pretreated at $7 \% \mathrm{NaOH}$ for $2 \mathrm{hr}$ and $10 \%$ $\mathrm{NaOH} 0.5$ hr.

It is possible that the lower yields encountered using the hydrolysis system were due to end-product inhibition [27], although for two pretreatments an increased level of theoretical of glucose yield was achieved compared to the equivalent ethanol yield in the SSF systems. This may have been due to the increased effectiveness of cellulase at $50^{\circ} \mathrm{C}$ or the potential inhibition of S. cerevisiae within the SSF system.

3.1.2. SSF of NaOH Pretreated Sawdust. Preliminary analysis showed that greater yields were achieved for glucose fermentation through hydration followed by in situ addition from the acclimatised inoculums. In addition, preliminary testing of the inoculation of the reactors showed that $0.5 \mathrm{hr}$ of hydration and direct inoculation into the reactor was favourable.

SSF systems of the sawdust pretreated with $\mathrm{NaOH}$ at $60^{\circ} \mathrm{C}$ produced ethanol yields exceeding the $2.6 \pm 2.0 \%$ produced by the untreated sawdust. Highest yields were observed after $96 \mathrm{hr}$ and $120 \mathrm{hr}$ for the majority of pretreatments conditions as shown in Figure 2, with ethanol levels beginning to decline after $120 \mathrm{hr}$. Only one reactor continued to produce ethanol after $120 \mathrm{hr}$; this was sawdust pretreated with $7 \% \mathrm{NaOH}$ for $0.5 \mathrm{hr}$ at $60^{\circ} \mathrm{C}$, when fermented in an SSF system at enzyme dosage of $9.1 \mathrm{FPU} / \mathrm{g}_{\mathrm{TS}}$.

The highest yield of ethanol from a $60^{\circ} \mathrm{C}$ pretreatment was 25.2\%; this result was obtained from samples treated with $10 \% \mathrm{NaOH}$ solution for $1 \mathrm{hr}$, using an enzyme dosage of $20.0 \mathrm{FPU} / \mathrm{g}_{\mathrm{TS}}$ after $120 \mathrm{hr}$ of SSF operation (Figure 2).

Low variance between many of the reactors operated at cellulase dosages of 9.1 and $20.0 \mathrm{FPU} / \mathrm{g}_{\mathrm{TS}}$ shown in Figure 3 indicates that sufficient enzyme loading was reached in a majority of samples, thus reaching the "plateau point." In contrast several samples increased yields significantly when cellulase dosage increased, with sawdust pretreated at $60^{\circ} \mathrm{C}$ with $10 \% \mathrm{NaOH}$ for 0.5 and $1 \mathrm{hr}$ showing increases of $122 \%$ and $219 \%$ in ethanol yields, respectively. The increases in yields with increased cellulase dosage may be due to cellulase being irreversibly adsorbed onto the remaining lignin, lowering free enzymes available to hydrolyse the cellulose, and inhibiting glucose and thus ethanol production $[44,45]$.

No significant correlation was observed with variation in pretreatment times for the reactors that received $9.1 \mathrm{FPU} / \mathrm{g}_{\mathrm{TS}}$. As shown in Figure 3(a), a slight proportional correlation between yield and alkali concentration existed, with the exception of pretreated samples $10 \%$ for $1 \mathrm{hr}$ and $9.1 \mathrm{FPU} / \mathrm{g}_{\mathrm{TS}}$ (Figure 3(b)). Increased yields at greater $\mathrm{NaOH}$ concentration were observed in reactors of $20.0 \mathrm{FPU} / \mathrm{g}_{\mathrm{TS}}$ loading.

When pretreated at $121^{\circ} \mathrm{C}$ improved yields were observed at a faster rate, ethanol yield of $30.6 \%$ was obtained after $72 \mathrm{hr}$ of SSF as shown in Figure 4. Similarly, samples exposed to $-20^{\circ} \mathrm{C}$ showed significant increases in ethanol production over $\mathrm{NaOH}$ pretreated samples at $60^{\circ} \mathrm{C}$.

Ethanol production from sawdust exposed to high temperature of $121^{\circ} \mathrm{C}$ showed significant increased yields, where sawdust treated at $121^{\circ} \mathrm{C}$ produced $82-123 \%$ more ethanol than sawdust pretreated using the same $\mathrm{NaOH}$ concentration and exposure time at $60^{\circ} \mathrm{C}$. In a similar way $-20^{\circ} \mathrm{C}$ for $2 \mathrm{hr}$ pretreatment produced $37-49 \%$ greater yields than samples pretreated at $60^{\circ} \mathrm{C}$ for $2 \mathrm{hr}$, as shown in Figure 4 .

A proportional relationship between the cellulose concentration, decrease in xylans content, and increase in ethanol production was observed, as predicted. This is likely due to increased enzyme access to cell interior with the removal of hemicelluloses and extractives [12].

3.1.3. Crystallinity Measurements. The absorbance ratio $A_{1330} / A_{898}$ showed greater change of the two absorbance ratios measured. The ratio decreased from $0.69-0.8$ to 1.0 , for all $60^{\circ} \mathrm{C}$ pretreated sawdust, from the 1.01 of untreated sawdust. The largest reduction in absorbance ratios occurred for samples pretreated at $10 \% \mathrm{NaOH}$ for $2 \mathrm{hr}$, where $0.69 \pm$ 0.15 and $0.65 \pm 0.14$ measured were for $A_{1330} / A_{898}$ and $A_{1425} /$ $A_{898}$, respectively.

When assessing $A_{1330} / A_{898}$ all $\mathrm{NaOH}$ pretreated samples produced lower ratios than 1.01 of untreated sawdust as shown in Figure 5; this indicates that there had been some conversion in all treatments. The reductions in the $A_{1435} / A_{898}$ results indicated that only the samples pretreated with $\mathrm{NaOH}$ of $7 \%$ and $10 \%$ concentration for 1 and $2 \mathrm{hr}(\mathrm{s})$, respectively, had the most significant change in cellulose state.

Considering the total crystallinity for samples pretreated at $60^{\circ} \mathrm{C}$ with $\mathrm{NaOH}$, it was observed that only those pretreated with $10 \% \mathrm{NaOH}$ had ratios below the 1.69 of untreated sawdust with $\mathrm{Abs} A_{1375} / A_{2900}$ ratios of $1.59 \pm 0.24,1.60 \pm 0.09$, 


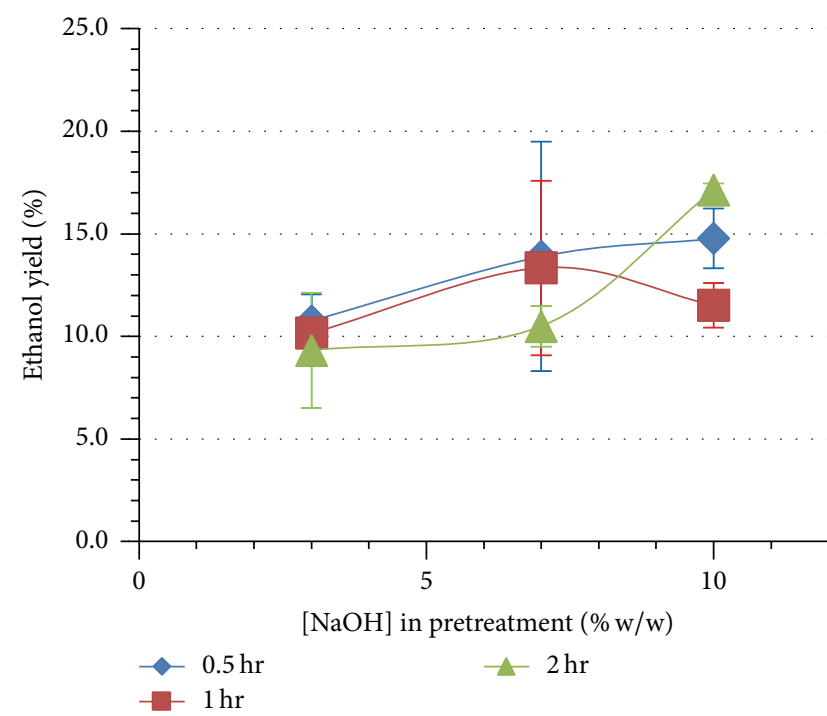

(a)

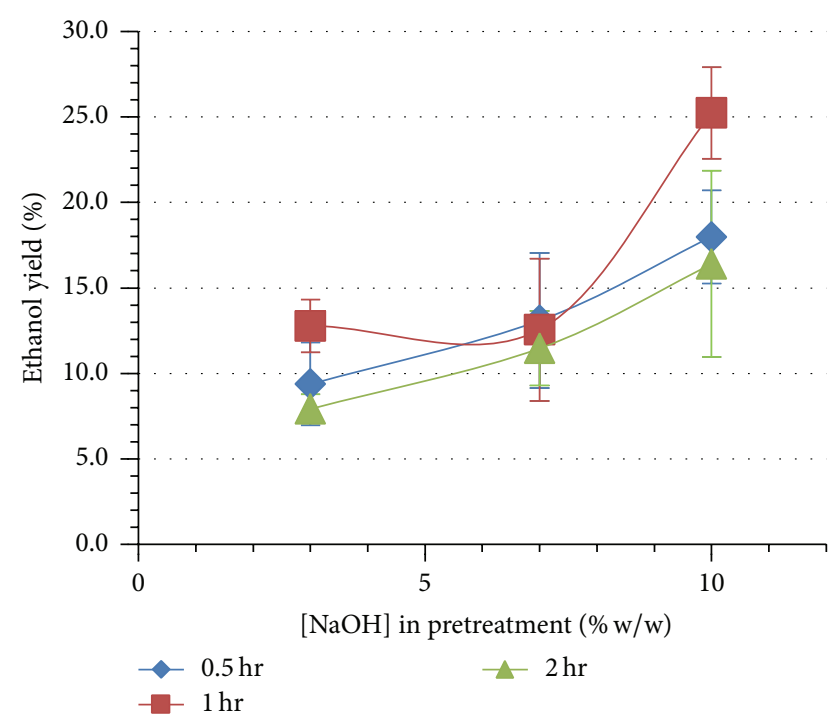

(b)

Figure 3: Ethanol yield from sawdust pretreated with $\mathrm{NaOH}$ at $60^{\circ} \mathrm{C}$ with enzyme dosage of (a) $9.1 \mathrm{FPU} / \mathrm{g}_{\mathrm{TS}}$; (b) $20.0 \mathrm{FPU} / \mathrm{g}_{\mathrm{TS}}$.

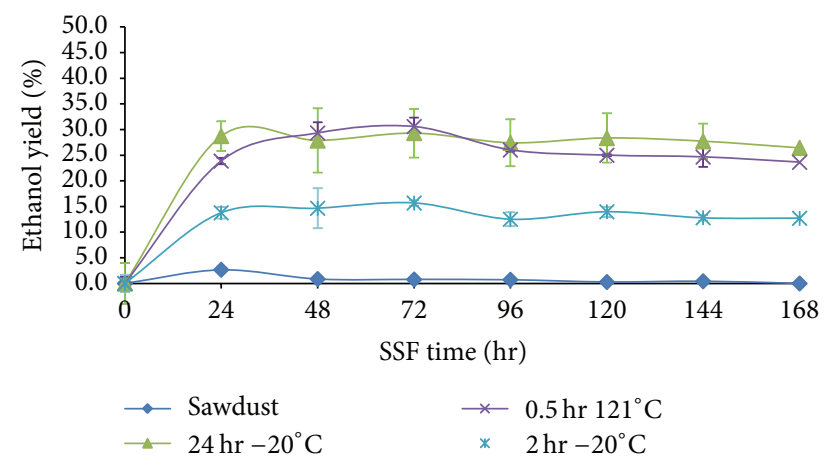

FIGURE 4: Ethanol yield from sawdust samples pretreated with $7 \%$ $\mathrm{NaOH}$ at $121^{\circ} \mathrm{C}$ and $-20^{\circ} \mathrm{C}$ using SSF system with $20.0 \mathrm{FPU} / \mathrm{g}_{\mathrm{TS}}$ cellulase.

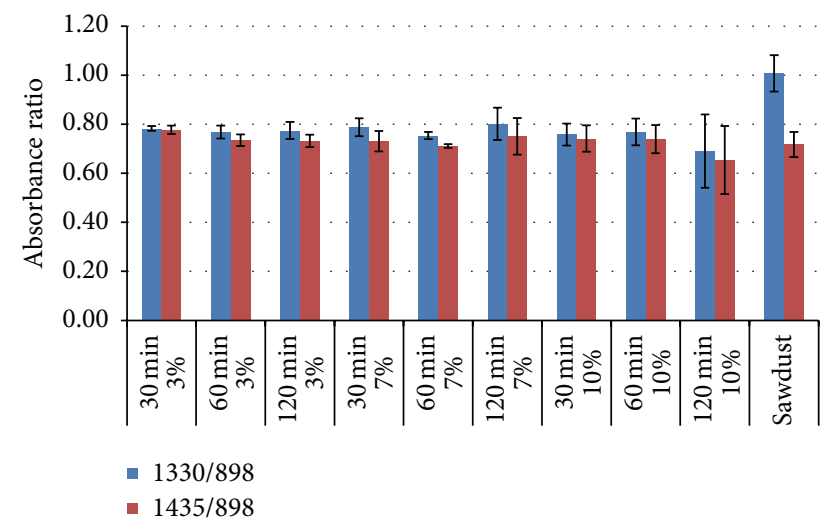

FIgURE 5: Absorbance ratios of $A_{1330} / A_{898}$ and $A_{1435} / A_{898}$ for sawdust pretreated with $\mathrm{NaOH}$ at $60^{\circ} \mathrm{C}$.

and $1.52 \pm 0.27$, for $0.5,1$, and $2 \mathrm{hr}$, respectively, as shown in Figure 6.

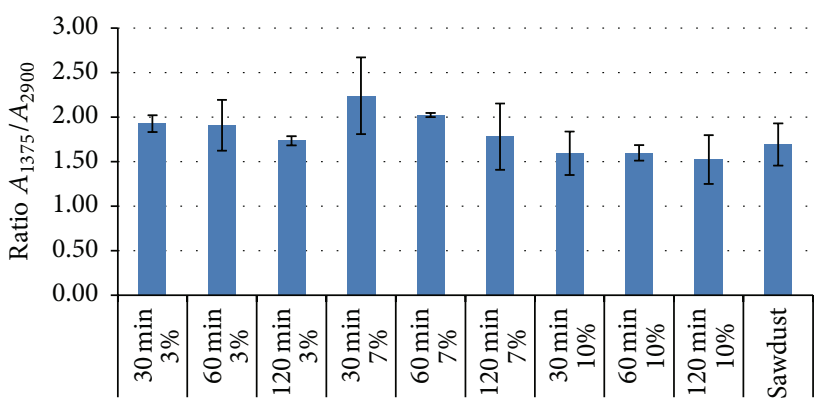

FIgURE 6: Total crystallinity of sawdust pretreated with $\mathrm{NaOH}$ at $60^{\circ} \mathrm{C}$.

The total crystallinity consistently decreased with increasing pretreatment times, although no apparent correlation exists relative to the ethanol yields. The largest increase in total crystallinity was $32 \%$, observed for samples pretreated with $7 \% \mathrm{NaOH}$ and $0.5 \mathrm{hr}$. From these results it appears that both time and concentration impact had an effect on total crystallinity. Increased concentrations of $\mathrm{NaOH}$ pretreatment at $60^{\circ} \mathrm{C}$ produced improved yields for the majority of conditions tested as discussed above (Figure 3). This indicates that increase in yield is likely aided by increased dissolution and subsequent production of amorphous regions of cellulose at greater $\mathrm{NaOH}$ concentrations $[17,44]$. The increase in amorphous regions in the cellulose microfibrils allows increased areas for bondage for progressive exoglucanase to hydrolyse the cellulose $[46,47]$. These structural changes are consistent with the observed changes to total crystallinity, with the samples pretreated with $10 \% \mathrm{NaOH}$ producing lower crystallinity than those pretreated with 3\% and 7\% as shown in Figure 6. The combined effect of changes to cellulose structure and reduction in hemicellulose is likely to be responsible for the increase in ethanol yield. 


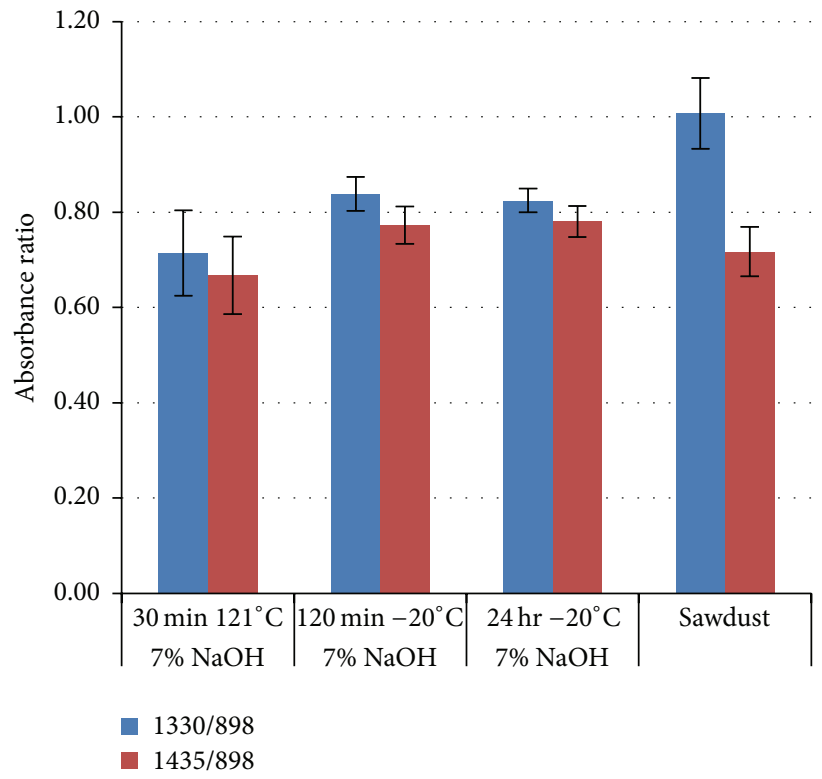

(a)

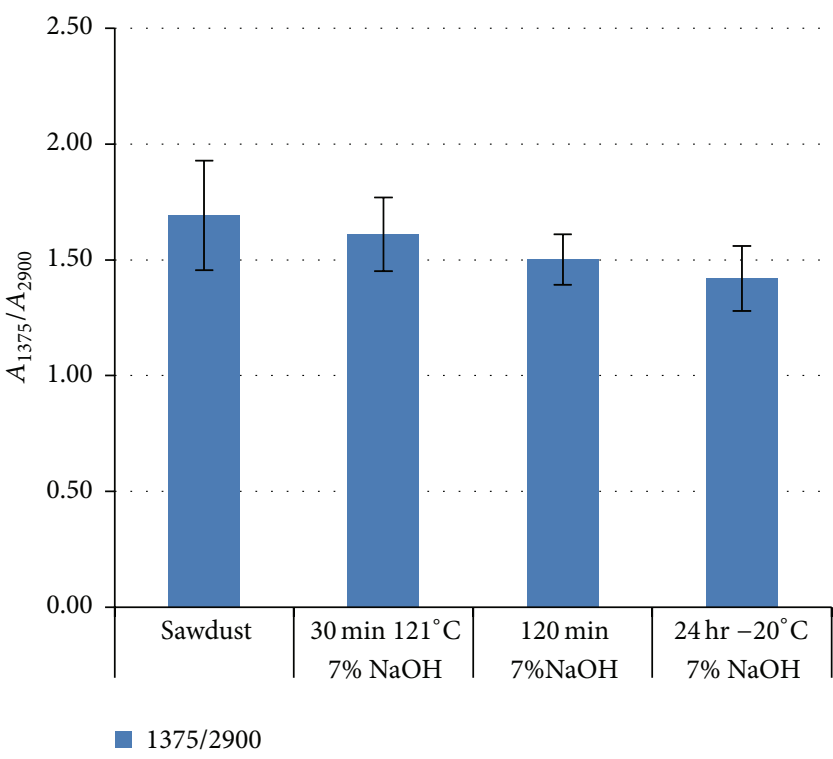

(b)

FIGURE 7: Crystallinity analysis of 7\% NaOH extreme conditions: (a) comparison of absorbance ratios; (b) comparison of total crystallinity index.

Absorption ratios $A_{1435} / A_{898}$ and $A_{1330} / A_{898}$ (Figure $7(\mathrm{a})$ ) of $7 \% \mathrm{NaOH}$ at 121 and $-20^{\circ} \mathrm{C}$ pretreatments had significant reduction from the $60^{\circ} \mathrm{C}$ pretreatments, but only pretreatment for $0.5 \mathrm{hr}$ at $121^{\circ} \mathrm{C}$ produced an $A_{1435} / A_{898}$ ratio lower than that of untreated sawdust with $29 \%$ and $7 \%$ reductions for $A_{1330} / A_{898}$ and $A_{1435} / A_{898}$, respectively.

Reduction in total crystallinity was observed for all $7 \%$ $\mathrm{NaOH}$ pretreated sawdust exposed to $121^{\circ} \mathrm{C}$ or $-20^{\circ} \mathrm{C}$. It was noted that pretreatments at $121^{\circ} \mathrm{C}$ for $0.5 \mathrm{hr}$ produced a $5 \%$ reduction in crystallinity which unlike analysis of absorbance ratios of $A_{1435}, A_{1330} / A_{898}$ was less of a reduction than that of pretreatment at $-20^{\circ} \mathrm{C}$, reduced by $11 \%$ and $16 \%$ for 2 and $24 \mathrm{hr}$, respectively (Figure $7(\mathrm{~b})$ ).

FTIR analysis of sawdust pretreated with $7 \% \mathrm{NaOH}$ for $0.5 \mathrm{hr}$ at 121 and $-20^{\circ} \mathrm{C}$ for $24 \mathrm{hr}$ showed peaks signifying bending in $\mathrm{CH}_{2}$ at C-6 in glucose shifted and was located at $1431 \mathrm{~cm}^{-1}$ associated with cellulose II instead of the cellulose $\mathrm{I} \beta$ peak location of $1427 \mathrm{~cm}^{-1}$ [37], further suggesting internal changes to the microfibril structure.

The high yields of samples pretreated at $121^{\circ} \mathrm{C}$ are likely due to the highest level of hemicellulose and lignin reduction as well as the most significant conversion of cellulose $\mathrm{I} \beta$ [12]. It was noted that $\mathrm{NaOH}$ pretreatment at $121^{\circ} \mathrm{C}$ produced the apparent complete removal of galactose and the largest xylan reduction, likely leading to the largest pore space production.

Similarly, samples that had been exposed to $-20^{\circ} \mathrm{C}$ showed increased yields due to the greater increase in amorphous cellulose, microfibril swelling, and the large reduction of xylans and galactans. The greater levels of amorphous cellulose would likely lead to reduction in crystallinity and likely larger internal areas [24, 47], increasing yields. Increased internal swelling may be due to impact on the internal hydrogen bondages within the microfibril structure bonding $\mathrm{Na}^{+}$ in place of water swelling structure [48]. Samples exposed to $-20^{\circ} \mathrm{C}$ for $24 \mathrm{hr}$ may have greater yields than their $2 \mathrm{hr}$ counterparts due to complete freezing of the sample, while samples exposed to only $2 \mathrm{hr}$ experienced partial freezing. The lack of complete freezing may have prevented optimum cleavage of the lignin hemicellulose bonds and microfibrils expansion, thus causing lower accessibility for enzymes, and reduced ethanol yields $[24,48]$.

\section{Conclusion}

Pretreatment at $60^{\circ} \mathrm{C}$ with $3-10 \% \mathrm{NaOH}$ could be used as a pretreatment to increase ethanol yields of sawdust produced in Australian timber mills. It was observed that the increased concentration of $\mathrm{NaOH}$ leads to an increase of ethanol yield, with exposure time not being the major factor between 0.5 and $2 \mathrm{hr}$. The increase in yield with enzyme dosage is likely linked to the increase in amorphous regions in the cellulose structure, the increased presence of cellulose II, and removal of extractives and hemicellulose. These combined factors increase enzyme ability to hydrolyse cellulose and remove inhibitors.

It was observed that the moderate temperatures of $60^{\circ} \mathrm{C}$ and short exposure time alkali pretreatment yielded less ethanol than samples exposed to either $-20^{\circ} \mathrm{C}$ or $121^{\circ} \mathrm{C}$ temperatures. This is likely due to the lower impact on crystallinity and cellulose state in conjunction with the lower levels of hemicellulose and lignin removal within these samples.

The most significant observed difference in the pretreatments at $-20^{\circ} \mathrm{C}$ and $121^{\circ} \mathrm{C}$ was the greater conversion to cellulose II and an improved removal of ASL observed in samples pretreated at $121^{\circ} \mathrm{C}$. Alternatively total reduction in crystallinity was greater in samples pretreated at $-20^{\circ} \mathrm{C}$, suggesting that although cellulose crystalline morphology had 
not been converted, the internal surface area of the cellulose microfibrils had likely been increased due to swelling and amorphous region production.

The use of combined $\mathrm{Ca}(\mathrm{OH})_{2}$ and $\mathrm{NaOH}$ or oxygenated alkali pretreatments may prove to be capable of pretreating timbers to a level of economic viability, but this requires further research. Alternatively, assessing the potential for reuse of the $\mathrm{NaOH}$ solutions used for pretreatment could potentially lead to an economically viable system, as $\mathrm{NaOH}$ recovery would account for a significant portion of the operational costs.

\section{Conflict of Interests}

The authors declare that there is no conflict of interests regarding the publication of this paper.

\section{Acknowledgments}

The authors would like to thank Smartwood and Business Victoria for funding this study, Enzyme Solutions Australia for providing the enzymes, and Lallemand Biofuels \& Distilled Spirits for providing yeast to undertake this research.

\section{References}

[1] L. A. Lucia, "Lignocellulosic biomass: a potential feedstock to replace petroleum," BioResources, vol. 3, no. 4, pp. 981-982, 2008.

[2] R. Chandra, H. Takeuchi, and T. Hasegawa, "Methane production from lignocellulosic agricultural crop wastes: a review in context to second generation of biofuel production," Renewable and Sustainable Energy Reviews, vol. 16, no. 3, pp. 1462-1476, 2012.

[3] Y. Sun and J. Cheng, "Hydrolysis of lignocellulosic materials for ethanol production: a review," Bioresource Technology, vol. 83, no. 1, pp. 1-11, 2002.

[4] J. Taylor and M. Warnken, Wood Recovery and Recyling: A Source Book for Australia, Forest and Wood Products Australia, Melbourne, Australia, 2008.

[5] S. McIntosh, T. Vancov, J. Palmer, and M. Spain, "Ethanol production from Eucalyptus plantation thinnings," Bioresource Technology, vol. 110, pp. 264-272, 2012.

[6] A. Mohsenzadeh, A. Jeihanipour, K. Karimi, and M. J. Taherzadeh, "Alkali pretreatment of softwood spruce and hardwood birch by $\mathrm{NaOH}$ /thiourea, $\mathrm{NaOH} /$ urea, $\mathrm{NaOH} /$ urea/thiourea, and $\mathrm{NaOH} / \mathrm{PEG}$ to improve ethanol and biogas production," Journal of Chemical Technology \& Biotechnology, vol. 87, no. 8, pp. 1209-1214, 2012.

[7] N. L. C. Silva, G. J. V. Betancur, M. P. Vasquez, E. de Barros Gomes, and N. Pereira Jr., "Ethanol production from residual wood chips of cellulose industry: acid pretreatment investigation, hemicellulosic hydrolysate fermentation, and remaining solid fraction fermentation by SSF process," Applied Biochemistry and Biotechnology, vol. 163, no. 7, pp. 928-936, 2011.

[8] A. Romaní, H. A. Ruiz, F. B. Pereira, J. A. Teixeira, and L. Domingues, "Integrated approach for effective bioethanol production using whole slurry from autohydrolyzed Eucalyptus globulus wood at high-solid loadings," Fuel, vol. 135, pp. 482-491, 2014.
[9] S. P. S. Chundawat, G. T. Beckham, M. E. Himmel, and B. E. Dale, "Deconstruction of lignocellulosic biomass to fuels and chemicals," Annual Review of Chemical and Biomolecular Engineering, vol. 2, pp. 121-145, 2011.

[10] Y. P. Timilsena, C. J. Abeywickrama, S. K. Rakshit, and N. Brosse, "Effect of different pretreatments on delignification pattern and enzymatic hydrolysability of miscanthus, oil palm biomass and typha grass," Bioresource Technology, vol. 135, pp. 82-88, 2013.

[11] R. B. Santos, E. A. Capanema, M. Y. Balakshin, H.-M. Chang, and H. Jameel, "Effect of hardwoods characteristics on kraft pulping process: emphasis on lignin structure," BioResources, vol. 6, no. 4, pp. 3623-3637, 2011.

[12] A. T. W. M. Hendriks and G. Zeeman, "Pretreatments to enhance the digestibility of lignocellulosic biomass," Bioresource Technology, vol. 100, no. 1, pp. 10-18, 2009.

[13] F. Huang, A. J. Ragauskas, and Z. Fang, Chemical Pretreatment Techniques for Biofuels and Biorefineries from Softwood, Springer, 2013.

[14] V. S. Chang and M. T. Holtzapple, "Fundamental factors affecting biomass enzymatic reactivity," Applied Biochemistry and Biotechnology, vol. 84, pp. 5-37, 2000.

[15] W.-H. Chen, S.-C. Ye, and H.-K. Sheen, "Hydrolysis characteristics of sugarcane bagasse pretreated by dilute acid solution in a microwave irradiation environment," Applied Energy, vol. 93, pp. 237-244, 2012.

[16] V. B. Agbor, N. Cicek, R. Sparling, A. Berlin, and D. B. Levin, "Biomass pretreatment: fundamentals toward application," Biotechnology Advances, vol. 29, no. 6, pp. 675-685, 2011.

[17] K. Mirahmadi, M. M. Kabir, A. Jeihanipour, K. Karimi, and M. J. Taherzadeh, "Alkaline pretreatment of spruce and birch to improve bioethanol and biogas production," BioResources, vol. 5, no. 2, pp. 928-938, 2010.

[18] E. Rojo, M. V. Alonso, J. C. Domínguez, B. D. Saz-Orozco, M. Oliet, and F. Rodriguez, "Alkali treatment of viscose cellulosic fibers from eucalyptus wood: structural, morphological, and thermal analysis," Journal of Applied Polymer Science, vol. 130, no. 3, pp. 2198-2204, 2013.

[19] Y. Wang, Cellulose fiber dissolution in sodium hydroxide solution at low temperature: dissolution kinetics and solubility improvement [Ph.D. thesis], Georgia Institute of Technology, 2008.

[20] A. L. Woiciechowski, L. P. de Souza Vandenberghe, S. G. Karp et al., "The pretreatment step in lignocellulosic biomass conversion: current systems and new biological systems," in Lignocellulose Conversion, pp. 39-64, Springer, Berlin, Germany, 2013.

[21] M. Wada, M. Ike, and K. Tokuyasu, "Enzymatic hydrolysis of cellulose I is greatly accelerated via its conversion to the cellulose II hydrate form," Polymer Degradation and Stability, vol. 95, no. 4, pp. 543-548, 2010.

[22] R. Potumarthi, R. Baddhe, S. Bhattacharya, V. Gupta, and M. Tuohy, Fermentable Sugars from Lignocellulosic Biomass: Technical Challenges, Springer, 2013.

[23] A. Iwaki, T. Kawai, Y. Yamamoto, and S. Izawa, "Biomass conversion inhibitors furfural and 5-hydroxymethylfurfural induce formation of messenger RNP granules and attenuate translation activity in Saccharomyces cerevisiae," Applied and Environmental Microbiology, vol. 79, no. 5, pp. 1661-1667, 2013.

[24] Y. Zhao, Y. Wang, J. Y. Zhu, A. Ragauskas, and Y. Deng, "Enhanced enzymatic hydrolysis of spruce by alkaline pretreatment at low temperature," Biotechnology and Bioengineering, vol. 99, no. 6, pp. 1320-1328, 2008. 
[25] V. S. Chang, B. Burr, and M. T. Holtzapple, "Lime pretreatment of switchgrass," Applied Biochemistry and Biotechnology, vol. 63, no. 1, pp. 3-19, 1997.

[26] J. Xu and J. J. Cheng, "Pretreatment of switchgrass for sugar production with the combination of sodium hydroxide and lime," Bioresource Technology, vol. 102, no. 4, pp. 3861-3868, 2011.

[27] M. Ballesteros, J. M. Oliva, M. J. Negro, P. Manzanares, and I. Ballesteros, "Ethanol from lignocellulosic materials by a simultaneous saccharification and fermentation process (SFS) with Kluyveromyces marxianus CECT 10875," Process Biochemistry, vol. 39, no. 12, pp. 1843-1848, 2004.

[28] S. Hari Krishna, T. Janardhan Reddy, and G. V. Chowdary, "Simultaneous saccharification and fermentation of lignocellulosic wastes to ethanol using a thermotolerant yeast," Bioresource Technology, vol. 77, no. 2, pp. 193-196, 2001.

[29] G. L. Miller, "Use of dinitrosalicylic acid reagent for determination of reducing sugar," Analytical Chemistry, vol. 31, no. 3, pp. 426-428, 1959.

[30] B. Adney and J. Baker, Measurement of Cellulase Activities, National Renewable Energy Laboratory, U.S. Department of Energy, 1996.

[31] J. McMillan and N. Dowe, SSF Experimental Protocols-Lignocellulosic Biomass-Hydrolysis and Fermentation, National Renewable Energy Laboratory, US Department of Energy, Golden, Colo, USA, 2001.

[32] M. Selig, N. Weiss, and Y. Ji, Enzymatic Saccharification of Lignocellulosic Biomass, National Renewable Energy Laboratory, U.S. Department of Energy, 2008.

[33] HACH-Company, Solids, Total Volatile and Fixed, 2012.

[34] A. Sluiter, B. Hames, R. Ruiz, C. Sacarlata, J. Sluiter, and D. Templeton, Determination of Ash in Biomass, National Renewable Energy Laboratory, US Department of Energy, Golden, Colo, USA, 2008.

[35] A. Sluiter, B. Hames, R. Ruiz et al., Determination of Structural Carbohydrates and Lignin in Biomass, National Renewable Energy Laboratory, U.S. Department of Energy, 2008.

[36] J. Łojewska, P. Miśkowiec, T. Łojewski, and L. M. Proniewicz, "Cellulose oxidative and hydrolytic degradation: in situ FTIR approach," Polymer Degradation and Stability, vol. 88, no. 3, pp. 512-520, 2005.

[37] S. Y. Oh, D. I. I. Yoo, Y. Shin et al., "Crystalline structure analysis of cellulose treated with sodium hydroxide and carbon dioxide by means of X-ray diffraction and FTIR spectroscopy," Carbohydrate Research, vol. 340, no. 15, pp. 2376-2391, 2005.

[38] K. K. Pandey and A. J. Pitman, "FTIR studies of the changes in wood chemistry following decay by brown-rot and white-rot fungi," International Biodeterioration \& Biodegradation, vol. 52, no. 3, pp. 151-160, 2003.

[39] N. Gierlinger, L. Goswami, M. Schmidt et al., "In situ FTIR microscopic study on enzymatic treatment of poplar wood cross-sections," Biomacromolecules, vol. 9, no. 8, pp. 2194-2201, 2008.

[40] P. Salehian, K. Karimi, H. Zilouei, and A. Jeihanipour, "Improvement of biogas production from pine wood by alkali pretreatment," Fuel, vol. 106, pp. 484-489, 2013.

[41] T. H. Kim, J. S. Kim, C. Sunwoo, and Y. Y. Lee, "Pretreatment of corn stover by aqueous ammonia," Bioresource Technology, vol. 90, no. 1, pp. 39-47, 2003.

[42] K. K. Pandey, "A study of the chemical structure of soft and hardwood and wood polymers by FTIR spectroscopy," Journal of Applied Polymer Science, vol. 71, no. 12, pp. 1969-1975, 1999.
[43] M. Schwanninger, J. C. Rodrigues, H. Pereira, and B. Hinterstoisser, "Effects of short-time vibratory ball milling on the shape of FT-IR spectra of wood and cellulose," Vibrational Spectroscopy, vol. 36, no. 1, pp. 23-40, 2004.

[44] B. Yang, Z. Dai, S.-Y. Ding, and C. E. Wyman, "Enzymatic hydrolysis of cellulosic biomass," Biofuels, vol. 2, no. 4, pp. 421450, 2011.

[45] A. Berlin, M. Balakshin, N. Gilkes et al., "Inhibition of cellulase, xylanase and beta-glucosidase activities by softwood lignin preparations," Journal of Biotechnology, vol. 125, no. 2, pp. 198209, 2006.

[46] M. Couturier and J.-G. Berrin, "The saccharification step: the main enzymatic components," in Lignocellulose Conversion, V. Faraco, Ed., pp. 93-105, Springer, Berlin, Germany, 2013.

[47] G. Yang, M. S. Jahan, L. Ahsan, L. Zheng, and Y. Ni, "Recovery of acetic acid from pre-hydrolysis liquor of hardwood kraft-based dissolving pulp production process by reactive extraction with triisooctylamine," Bioresource Technology, vol. 138, pp. 253-258, 2013.

[48] P. Zugenmaier, "Conformation and packing of various crystalline cellulose fibers," Progress in Polymer Science, vol. 26, no. 9, pp. 1341-1417, 2001. 


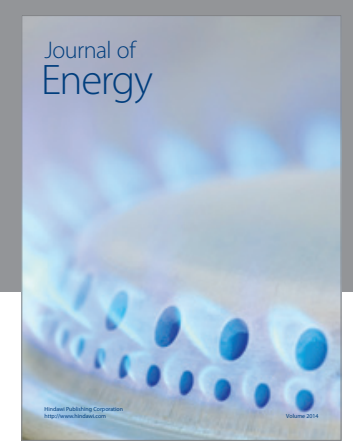

Journal of

Industrial Engineering
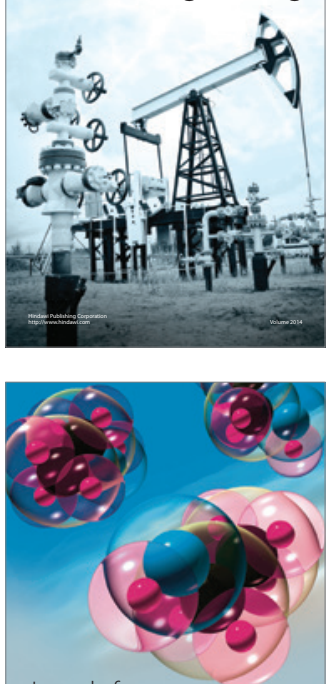

Fuels
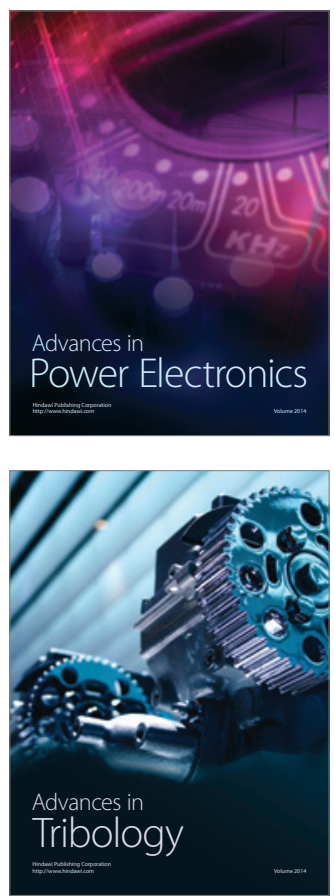

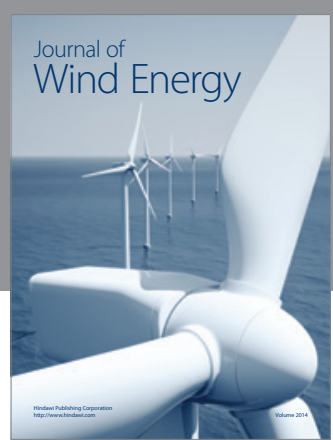

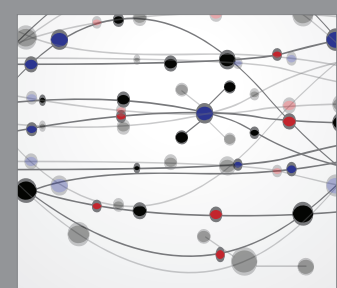

The Scientific World Journal

Submit your manuscripts at http://www.hindawi.com

Journal of

Structures
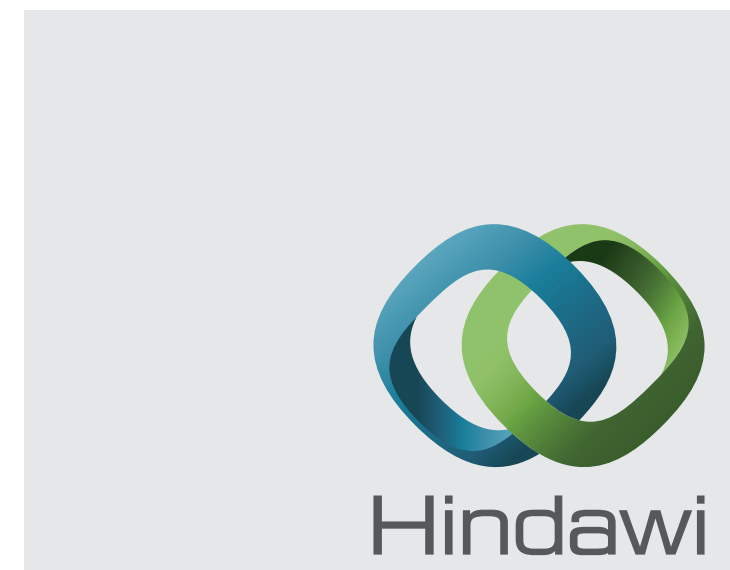

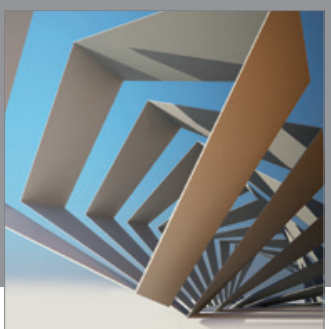

Rotating

Machinery
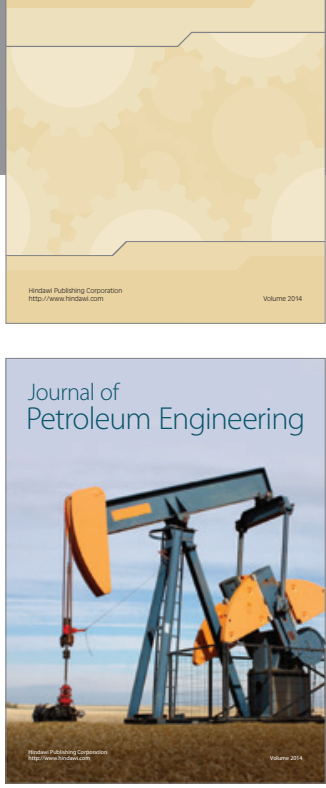

Journal of

Solar Energy
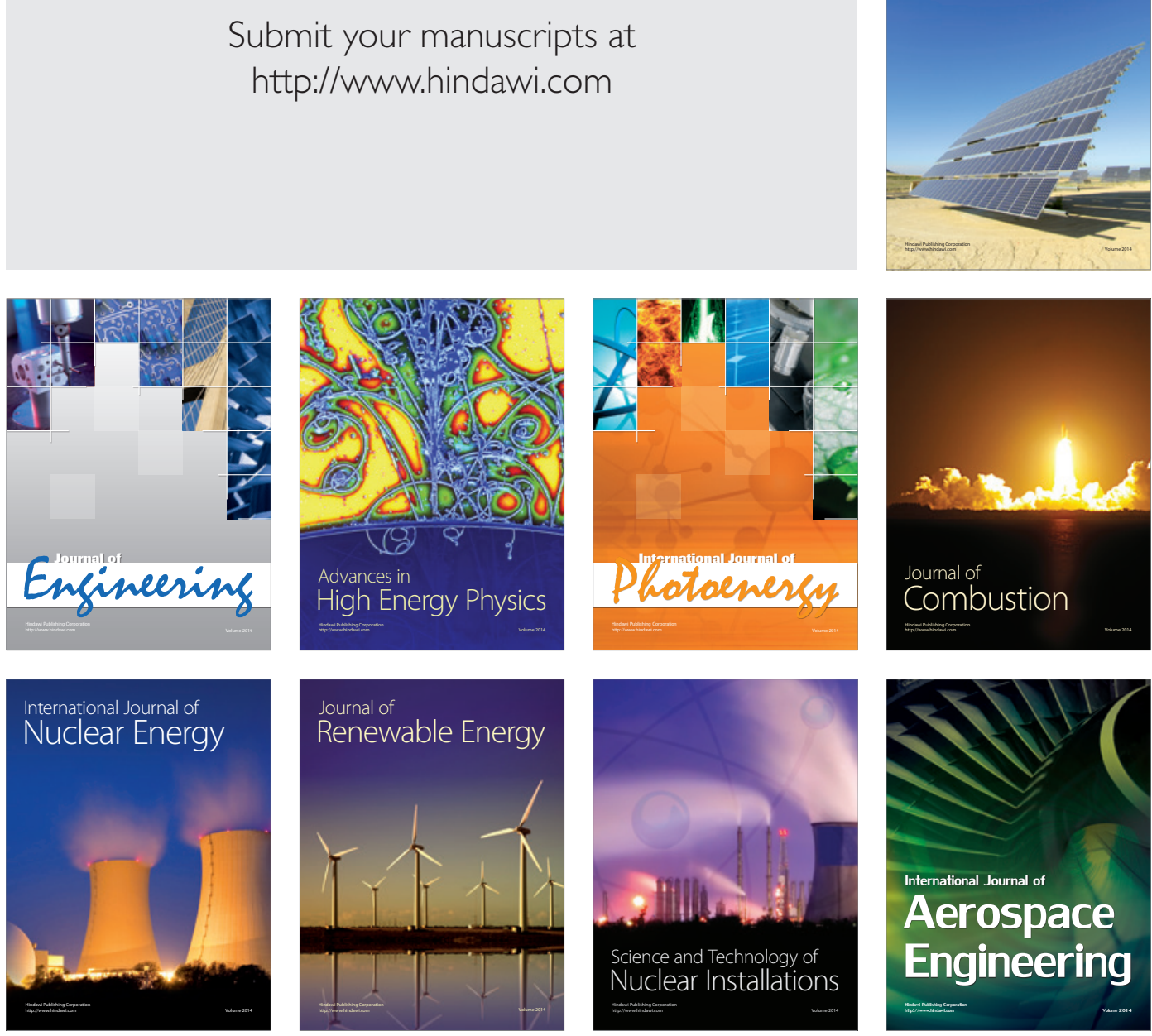